\title{
給付つき税額控除制度とは？ 一その概要と意義·問題点
}

\section{埋橋孝文}

\section{1. はじめに}

本小文は、わが国で最近注目されている「給 付つき税額控除制度 (refundable tax credit)」 について、その概要を紹介し、なぜ近年日本で 注目されるようになってきているかという背 景を説明する。次いで、その意義を明らかにし、 同時にその問題点を指摘する。

税は基本的に次の計算式で算定される。

税 $=$ 課税所得 $(=$ 粗所得 - 所得控除 $) \times$ 税率 - 税額控除

給付つき税額控除とは、税 <税額控除の場合 にその差額を「給付」するものである。所得控 除が税率を掛ける前に控除されるのに比べて 税額控除は税率をかけた後に 控除される。一見技術的な違 いのようだが、再分配効果が 両者では異なるし、そもそも 税とは何かという原理的な問 題も惹起する。また、日本で 給付つき税額控除制度が導入 されれば（風吹けば） $\Rightarrow$ 税理 士法の改正・税理士会の猛反 対（桶屋が儲かる）といった 波及効果も大きい。
図 1 アメIJカ稼得所得税額控除 (Earned Income Tax Credit, EITC)

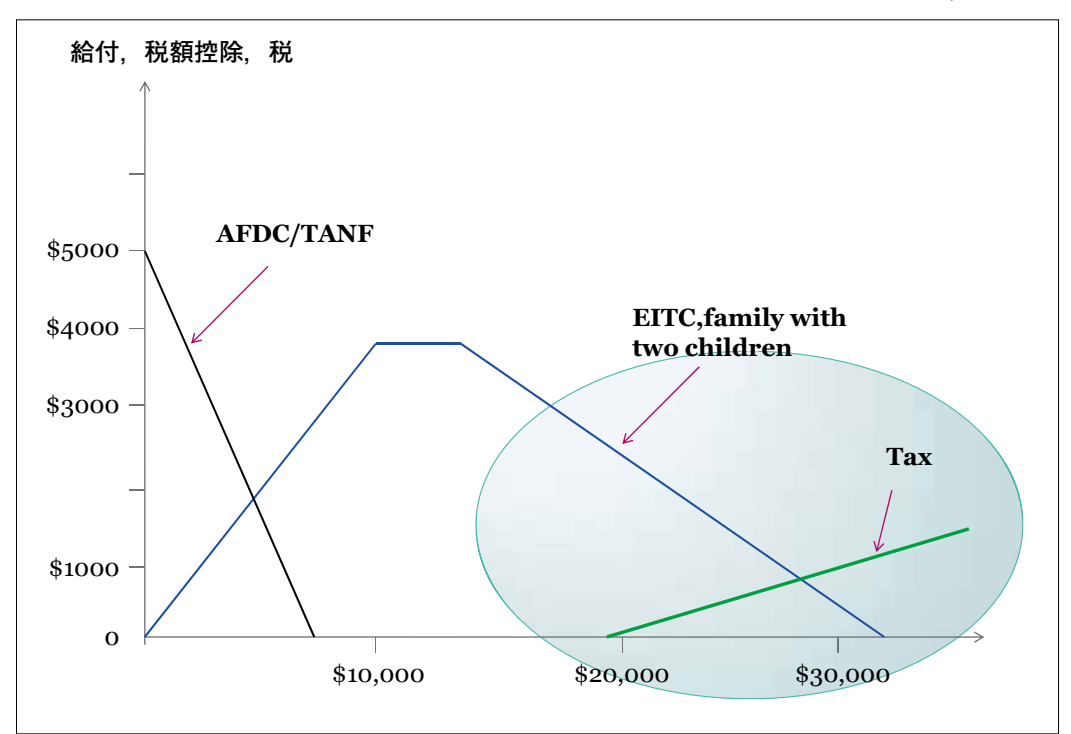

出所）Hoffman \& Seidman(2003)22,114頁から作成 
初に実施したのはアメリカである。

給付つき税額控除制度は設計がフレクシブ ルなのが特徴であり、それに応じて多様な型が 生まれる。たとえば、給付つきにするかどうか、 〈フェーズイン＞、＜定額〉、〈フェーズアウ ト>をどのように組み込むか、就業条件を付け るかどうか、個人単位か世帯単位か、受給条件、 対象個人、世帯をどのように設定するか、等に よっていくつものヴァリエーションが生まれ る。ただし、共通しているのは「働いている低 所得者層」の所得保障を狙いとした「政策税制」 であることである。

\section{3. なぜ給付つき税額控除制度が 注目されるようになったのか、 その背景}

その背景としては、第一に、グローバリゼー ションの進展に伴う格差の拡大と低所得者対 策の浮上、第二に、積極的社会政策の登場とワー クフェアの国際的席巻、という事情を考えるこ とができる。

第一の点については補足説明の必要がない かもしれないが、とりわけヨーロッパでは、一 方でグローバリゼーションや新自由主義の影 響を受け、たとえば公的年金スリム化などの措 置が講じられつつも、その一方で、いわゆる 低所得者対策が強化されてきていることに注 意する必要がある（有森［2007］を参照）。ま

\section{PROFILE}

埋橋孝文

(うずはし たかふみ)

同志社大学社会学部社会福祉学科 教授

専門：社会政策・社会保障論、比較 福祉国家論
た、アメリカでは先にふれたようにワーキング プアに対する実質的には現金給付制度である 給付つき税額控除制度が年々充実してきてい るし、あまり知られていないが、基礎的な所得 を保障する社会保障年金（OASDI）は「現役 時の所得階層の低いものほど高い所得代替率 が保障され、高所得者への所得代替率は低くな る」ように設計されており所得再分配効果の高 いものとなっている（吉田 [2009]）。

第二の点は、第一の流れと並行して、「福祉 依存 (Welfare dependency)」が問題視され、 そうした事態を避けるべく、福祉給付を受け取 るためには就業を条件にする動き、労働インセ ンティブを損なわない給付の設計が重視され ていることである。いわゆるワークフェアへの 傾斜であるが、それは今日、「働くことがペイ する (報われる)」(Making Work Pay) 政策 と表螤一体に実施されている（こうした点につ いては埋橋編著「2007」を参照)。

そしてこの Making Work Pay 政策の代表が 給付つき税額控除制度であるが、OECD30 力国 のなかで7カ国（カナダ、チェコ、デンマーク、 イタリア、オランダ、スロバキア、トルコ）が 
近年所得控除方式を税額控除方式へ全面転換 し、5 カ国が部分的に転換、14 力国が以前から 導入している。4カ国（ギリシャ、ノルウェー、 スイス、日本) だけが導入していない。

\section{4. 給付つき税額控除制度の 二つの具体的提言}

給付つき税額控除制度への関心の高まりに 呼応して以下のような具体的提言が出されて いる。

(1)「日本型児童税額控除」東京財団 （森信編著 [2008]）

内容: 扶養控除、配偶者控除を各 20 万円減額（税 収中立)、課税所得 200 万円（夫婦子供 2 人で給 与所得 600 万円）以下で 23 歳以下の扶養親族を 持つ納税者に扶養親族 1 人当たり年 5 万円の税 額控除、年末調整（自営業者は確定申告）時に 税額控除、市町村を通して給付（還付）、この 提案は「税収中立」であることに特色がある。

(2)「ワーキングプア対策としての給付つき税額 控除」(埋橋十連合総研編 [2010]図2参照) 内容：対象は現役世代のワーキングプア（推定 555 万人、参考・アメリカの 2006 年 EITC 受給 者数 2,240 万人)、所得制限（世帯）=生活保護 基準、給付単位は個人、税額控除額の最高金額 年間 31.2 万円、単純な必要財源 1 兆 7,000 億円。 将来的には所得控除の縮小、廃止を視野に入れ ている。この提案は、以下の引用文が示すよう に、働くことに対する「参加手当」の導入を主
張している。

「本制度は、生活保護制度のように『最低生 活費』までの差額分をすべて補填する制度では ない。その意味で、本制度のみでは、ワーキン グプアの最低生活は保障されない。しかしな がら、本制度からの税額控除と、潤沢な子ど もに対する『子ども手当』、および、本書の各 章で述べられている医療費補助や住宅補助の 現物を保障する給付を加えることにより、ワー キングプアの生活の大幅な改善が期待される」 (259-60頁)

\section{まとめ}

低所得層の所得保障を図る上で、最低賃金制 に比べてターゲット効率性に優れ、また、フレ クシブルな制度設計上の特性を生かして労働 インセンティブ問題を回避しながら個々の政 策課題を実現することができる。とりわけ社会

\section{図2 給付つき税額控除額の設計}

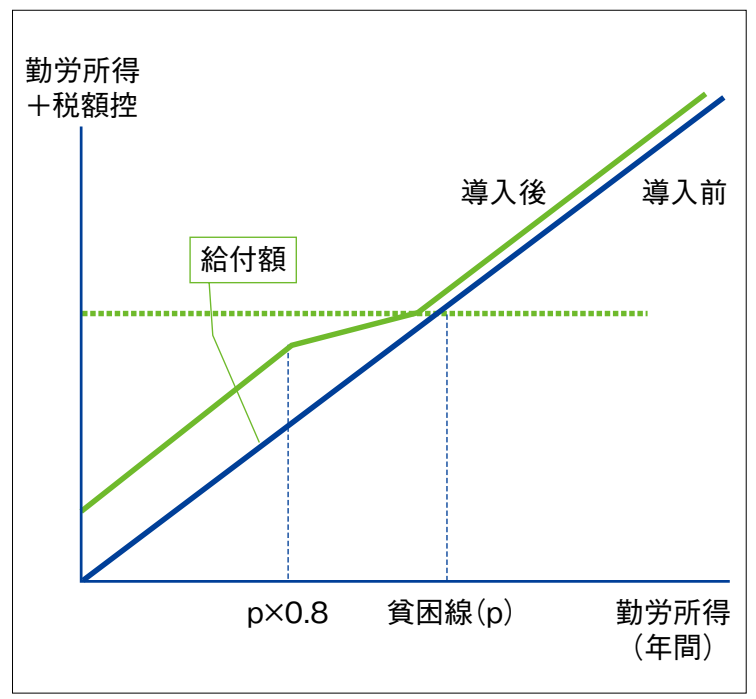

出所）埋橋＋連合総研（2010）257頁 
手当・社会サービスが貧弱で、その結果、社会 保険と生活保護の両方の網から漏れるワーキ ングプアが多い日本では彼らの所得の下支え を実現できる。

\section{5. 給付つき税額控除制度の問題点}

給付つき税額控除制度をめぐっては「地獄へ の道は善意の石で敷き詰められている」（渡辺 [2008]）とも云われるように、いくつかの検討 課題が指摘されている。それらを技術的問題と 原理的問題に分けて説明すれば以下のとおり である。

\section{1）技術的問題}

現在の課税最低限の人々の所得についても、 きちっとした情報がないと、いくら給付したら いいかということがわからないことがまず指 摘され、一方、「申告」形式をとると不正申告 が生じる可能性があり、また、個々の税務調査 は執行コストがかかり過ぎる点が挙げられる。

\section{2) 原理的問題}

\section{(1)経済的問題}

経済的問題としては以下の問題が指摘され ている。

1.「事後的」な所得補償措置であり、生活保 障機能が弱い点（アメリカの場合 1 年に 1 回給付)。

2. アメリカのようなフェーズイン部分があ ると何らかのやむを得ない理由で前年の
所得が減った場合に今年の給付が減る。

3. フローの所得を基準とするため資産のあ る人にも給付の可能性がある。

4. 低賃金雇用への実質的な助成であり、雇 い主の人的資本への投資を抑制し、低賃 金雇用を温存する。

\section{(2)税財政法上の問題}

アメリカのEITCをめぐっては、不正給付（過 大還付申告）問題がやはりいちばん大きな問題 のようである。金額ベースで2004年 23 ～28\% （IRS調べ）が不正給付であるといわれている （石村 [2008]）。ただし、離婚や再婚の割合が 大きいアメリカの家族事情がその背景にある ともいわれ、わが国ではそれほど不正率は高く ないであろうという意見もある。

わが国に導入する際により重要で、クリアし なければならない点は、タックス・コンプライ アンスの問題である。「働いても貧しい人たち は概して年末調整手続きの枠外に置かれてい る。……急いで検討を要するのは非正規雇用に 忍従し転職回数も多い、働いても貧しい給与所 得者層」（石村 [2008]）であり、かれらに対し て、アメリカで広範なNPOが協力して行なわ れているような「申告前支援」「申告期支援」「申 告後支援」をどのように担保するかという問題 である。日本の税理士法では税業務の絶対独占 (たとえ無償であっても繰り返し行うことは違 法）があるのでまずそれをどのように改めてい くかが問われることになる。 


\section{6. おわりに}

給付つき税額控除制度は「万能薬」ではない し、実施に向けてのインフラ・条件整備の余地 も大きい。基本的には税支出の形をとるのがい いのか、あるいは社会保障給付の形のほうが望 ましいのかを詰める必要がある。また、納税者 番号・社会保障カードの導入や確定申告のサ ポート体制をどう作り上げるのかという課題 がある。

しかし、制度の谷間で呻吟している500万人 を超えるワーキングプアに対するセーフティ ネットの再構築は急務の課題であり、税制とし て何ができ、何ができないかを明らかにしてく 必要がある。予想される消費税導入時に「消費 税逆進性対策税額控除」を導入するというのも 一つの手（「制度の頭出し」）と思われる。

\section{参考文献}

有森美木（2007）「先進各国の公的年金制度と高齢低所得者対 策」『海外社会保障研究』158号

石村耕治（2008）「給付（還付）つき税額控除をめぐる税財政 法上の課題一アメリカの『働いても貧しい納税者』対策税 制を検証する」『白鴎法学』15（1）

埋橋孝文編著（2007）『ワークフェアー排除から包摂へ?』法 律文化社

埋橋孝文＋連合総研（2010）『参加と連帯のセーフティネット』 ミネルヴァ書房

小川正雄（2010）「民主党・税制改正大綱と給付付き税額控除」 『税制研究』57

菅隆徳（2010）「民主党税制改正は『公平』か」『税制研究』 57

田近栄治・八塩裕之「所得税改革一税額控除による税と社会保 険料負担の一体調整」『季刊社会保障研究』44（3）

田中聡一郎 (2009)「給付つき税額控除の活用」『社会政策研究」 No.9

谷川喜美江（2009）「給付付税額控除制度の問題点」税務会計 研究学会『税務会計研究』(20)

——（2009）「所得税における控除制度の問題点」『嘉 悦大学研究論集』51 (3)

益子良一（2010）「所得税・改正の方向性の考察」『税制研究」 57

森信茂樹編（2008）『給付つき税額控除一日本型児童税額控除 の提言』中央経済社

森信茂樹 (2010)「給付付き税額控除の具体的設計」『税経通信』 $65(4)$

安田純子（2009）「講座 欧米諸国の低所得者政策22 給付付 き税額控除(1)」『週刊社会保障』2552

（2009）「講座 欧米諸国の低所得者政策23 給付付 き税額控除(2)」『週刊社会保障』2553

吉田健三（2009）「アメリカの年金システム」『海外社会保障 研究』171号

渡辺智之（2008）「所得税額はマイナスになりうるか? 一いわ ゆる「給付つき税額控除」の問題点」『租税研究』707

Blanc, R.M. et al (eds.) (2006) Working and Poor, Russell Sage Foundation

Carolyn, J. et al (2009) Making the Work-based Safety Net Work Better, Russell Sage Foundation

Hoffman, S.D. \& L.S.Seidman (1990) The Earned Income Tax Credit, W.E.Upjohn Institute

(2003) Helping Working Families,

W.E.Upjohn Institute

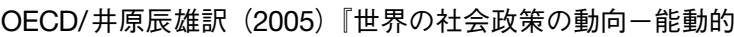
な社会政策による機会の拡大に向けて』明石書店 